\title{
Dependence and precarity in the platform economy
}

\author{
Juliet B. Schor ${ }^{1} \cdot$ William Attwood-Charles ${ }^{2} \cdot$ Mehmet Cansoy $^{3}$. \\ Isak Ladegaard ${ }^{4} \cdot$ Robert Wengronowitz $^{5}$
}

Published online: 7 August 2020

(C) Springer Nature B.V. 2020

\begin{abstract}
The rapid growth of Uber and analogous platform companies has led to considerable scholarly interest in the phenomenon of platform labor. Scholars have taken two main approaches to explaining outcomes for platform work - precarity, which focuses on employment classification and insecure labor, and technological control via algorithms. Both predict that workers will have relatively common experiences. On the basis of 112 in-depth interviews with workers on seven platforms (Airbnb, TaskRabbit, Turo, Uber, Lyft, Postmates, and Favor) we find heterogeneity of experiences across and within platforms. We argue that because platform labor is weakly institutionalized, worker satisfaction, autonomy, and earnings vary significantly across and within platforms, suggesting dominant interpretations are insufficient. We find that the extent to which workers are dependent on platform income to pay basic expenses rather than working for supplemental income explains the variation in outcomes, with supplemental earners being more satisfied and higher-earning. This suggests platforms are free-riding on conventional employers. We also find that platforms are hierarchically ordered, in terms of what providers can earn, conditions of work, and their ability to produce satisfied workers. Our findings suggest the need for a new analytic approach to platforms, which emphasizes labor force diversity, connections to conventional labor markets, and worker dependence.
\end{abstract}

Keywords Airbnb · Algorithmic control · Economic dependence · Platform labor · Precarity $\cdot$ Sharing economy $\cdot$ Uber

The rapid growth of Uber and analogous platform companies has led to considerable scholarly interest in the phenomenon of platform labor. While the number of platformbased workers is relatively small (1.9 million in 2016), it is growing rapidly (Collins et al. 2019) and many observers believe it is a harbinger of what will become the dominant form of labor relation (Huws et al. 2018; Kenney and Zysman 2016; Scholz 2016). Management theorist Gerald Davis has predicted widespread "Uberization" in

Juliet B. Schor

Juliet.schor@bc.edu

Extended author information available on the last page of the article 
which companies abandon long-term contracts in favor of task-based work, employeefree organizations, and an organizational structure akin to a "web page" rather than the modern corporation (Davis 2016a, b; Vallas 2019). Economist Arun Sundararajan also foretells an "end to employment" (Sundararajan 2016), but in this view, independent agents are able to self-employ profitably, using technology to gain freedom, autonomy, and livelihood. A third position sees platforms as twenty-first century entities that use digital tools, and specifically algorithms, to control and manipulate workers (Rosenblat 2018; Rosenblat and Stark 2016; Lee et al. 2015). These examples represent the three main approaches with which scholars have attempted to analyze this new economic form - precarity, efficiency, and algorithmic control. While each of these approaches focuses on an important aspect of platform labor, their emphasis on a single feature is misleading. In contrast, we argue that what is distinctive about the platforms is that the combination of open employment and earners' authority to self-schedule and organize work with considerable centralized power afforded by the firm's software. While we agree that platform work represents a new type of labor regime, our findings suggest that existing accounts have not recognized important implications of this combination.

Like precarious work itself (Vallas and Kalleberg 2018) platform labor is undertheorized, due to particularities in the evolution of the literature. One is a heavy focus on whether sharing platforms are beneficial or exploitative for workers, at the expense of a more analytic approach (Schor and Attwood-Charles 2017). A second is the "Ubercentricity" of research. Much of the interview and ethnographic data of in-person platform labor comes from ride-hailing, and Uber in particular (Robinson 2017; Rosenblat 2018; Malin and Chandler 2017; Peticca-Harris et al. 2018; Manriquez 2019; Dubal 2017a), with a smaller group of studies on food delivery (AttwoodCharles 2019a; Drahokoupil and Piasna 2019; Ivanova et al. 2018; Shapiro 2018). While ride-hail is the largest employer on labor platforms, it is not representative of many other platforms in terms of the characteristics of its labor force and degree of algorithmic management. Our approach, emphasizing analytic features of multiple platforms, yields different conclusions. In contrast to precarity scholars, we show that the openness of the employment relation yields a heterogeneous workforce with high variation in conditions of work and by extension, levels of precarity. Heterogeneity results because the firm "retreats" from controlling hours, scheduling, and the labor process, a ceding of management direction made possible by technology. However, in contrast to efficiency scholars, we find that firms do have power over workers in ways that competitive market theory cannot account for. And in contrast to algorithmic control theorists, we argue that control is mediated by workers' market situations, and that levels of control vary across platforms.

Our research is one of the few qualitative studies of different types of platform-based services. To date, there is no comparable multi-platform dataset, as previous efforts involve fewer platforms (Ravenelle 2019; Ticona et al. 2018). ${ }^{1}$ We argue that a multiplatform study offers the ability to develop a more general account of platform labor. Our finding of heterogeneity in workers' situations and experiences also casts doubt on

\footnotetext{
${ }^{1}$ Ravenelle's four platform study (Airbnb, Uber, TaskRabbit and Kitchensurfing) is closest to ours. Our results differ in a number of ways - we have a whiter sample and the New York City labor market is more competitive and more difficult for earners. For a discussion of these issues, see Schor (2017). Ravenelle's findings are also more negative, which may be partly a matter of emphasis (see note 8 ).
} 
a common assumption in labor market theorization, which is that workers doing the same job for the same employer will have broadly similar experiences. We find that platform labor belies that assumption. The openness of the employment relation yields diverse outcomes even when the formal category of employment (i.e., independent contractor) and technology are identical. We find strong differentiation across platforms, as well as across workers on a single platform, with respect to job satisfaction, remuneration, autonomy, and management control.

Our research is based on a seven platform qualitative study of providers in the Boston area. We confine our focus to consumer-oriented companies, frequently referred to as "the sharing economy." We have conducted 112 in-depth interviews with providers on Airbnb, TaskRabbit, Uber, Lyft, Postmates, Favor, and Turo. We find that the combination of open employment and technological management results in providers' experiences that are driven in large part by the economic situations they bring to the platforms, and in particular by how economically dependent they are on platform earnings. We describe platform conditions for providers, focusing on the adequacy of earnings, the effort/earnings bargain, autonomy and flexibility, and overall satisfaction. We find that when platform income is supplemental (1.e., the provider has multiple sources of income), satisfaction is higher, autonomy is greater, hourly wages are generally higher and conditions are better. By contrast, those who are dependent on the platform to fund basic living expenses express more dissatisfaction and experience more precarity. While economic dependence is also relevant in other workplaces, its importance is heightened in this context because the labor force is more situationally diverse than in conventional employment. Ours is the first article to analyze explicitly the role of economic dependency in the platform context, although the concept has been noted in the literature (Kuhn and Maleki 2017; Lehdonvirta 2018; Berg and Rani 2018; Ravenelle 2019).

We also find a second axis of variation across platforms. Although platforms are generally open to almost everyone, ${ }^{2}$ the asset requirements and skill levels needed to succeed vary considerably, as do outcomes. The platform economy is nested within the general labor market and larger trends in the availability and quality of jobs influence experiences of platform labor. We find that in order to achieve positive outcomes for their workers, platforms are free-riding on the security provided by conventional employment, suggesting a parasitic relationship between the two labor markets.

We believe that our emphasis on economic dependence, the hierarchy of the platform eco-system, and the parasitic relationship between platform and conventional labor, represents a new way to understand the phenomenon of platform work.

\section{Dominant approaches to platform labor}

Across the social sciences, there are marked differences in how scholars understand platform activity. Economists offer a common narrative of platform work, emphasizing efficiency and opportunity (Edelman and Geradin 2016; Sundararajan 2016). Within sociology, there are two major camps - precarity and algorithmic control (Vallas and

\footnotetext{
${ }^{2}$ There are some barriers such as certain types of criminal records or lack of institutional banking although these vary by the platform.
} 
Schor 2020). Precarity scholars see platform labor as the next stage in an ongoing process of precarization (Vallas and Kalleberg 2018; Scholz 2016; Ravenelle 2019) which has replaced the full-time, stable employment of the postwar era. Many focus on policy choices, most notably employment versus independent contracting (Dubal 2017a, b; Rogers 2015; Cherry 2016; Tomassetti 2016; Rahman and Thelen 2018; Kennedy 2017). The second camp argues that digital technologies distinguish platforms from conventional firms, and that algorithmic control is the crucial factor in workers' experiences. These scholars emphasize discontinuity with previous systems of labor control (Rosenblat and Stark 2016; Rosenblat 2018; Calo and Rosenblat 2017; Wood et al. 2019; Cameron 2020; Lee et al. 2015; Ivanova et al. 2018).

Precarity scholarship is part of a larger, longstanding body of research across the social sciences that understands labor outcomes within the context of historically varying institutional regimes that align state and corporate policy. Examples include the French "Regulation School" (Boyer and Saillard 2002) and the American "Social Structures of Accumulation" approach (Bowles et al. 1986), both of which focus on the institutional specificity of regimes of capital accumulation and labor control. Scholars distinguish the laissez-faire labor regime of the nineteenth century from the post-WWII social contract, in which employers afforded high levels of security to their workers, passed on productivity increases as higher wages, and tolerated labor unions (Marglin and Schor 1989; Burawoy 1979; Kalleberg 2018). Some scholars emphasize varieties of capitalism and national differences (Hall and Soskice 2001; Thelen 2014), however they also focus on dominant national institutional frameworks. The breakdown of the postwar regime is understood as a return to nineteenth-century market-based processes for managing and remunerating labor, described as the "great risk shift," "fissured workplace," "precariat," and "Polanyian double-movement" (Hacker 2008; Kalleberg 2013, 2018; Standing 2011; Weil 2014; Beck 2000; Hatton 2011). This literature identifies firm-led institutional restructuring as the driving force undermining the security and liveable wages of the postwar regime and creating precarity. Marketbased labor regulation also entails more frequent and longer durations of unemployment, including for the white-collar and highly educated workers (Chen 2015; Lane 2011; Sharone 2013), who eventually became a source of platform labor.

From this perspective, precarity reaches its apogee in the platform economy, which is seen as part of this larger trend, rather than something fundamentally new (Collier et al. 2017; Rahman and Thelen 2018; van Doorn 2017; Vallas 2019). This approach has focused on the use of independent contractor status rather than traditional employment, and the charge of misclassification, particularly by Uber (Dubal 2017a, b; Cherry 2016; Kennedy 2017; Rogers 2015). Misclassification is seen to give "immunity" (van Doorn 2017) to companies and buyers, by shifting responsibility and risk onto workers (Ravenelle 2019; Robinson 2017; Ladegaard et al. 2018). Re-classification as employees and achieving collective voice is therefore key to improving working conditions and altering platform outcomes, although some are pessimistic about the likelihood of such reforms (Collier et al. 2017).

While the precarity approach has obvious strengths, it can downplay the role of digital technology, including how it enables freedom and autonomy as it obviates direct control. Furthermore, some of these accounts are very pessimistic, seeing only risk and downward mobility, and over-emphasizing continuity with past practices. By contrast, those who focus on either efficiency or algorithmic control emphasize the role of technology. Economists credit digital 
matching, seamless payment systems, and reduced transaction costs (Edelman and Geradin 2016; Horton and Zeckhauser 2016; Cramer and Krueger 2016) in these efficient multi-sided markets (Rochet and Tirole 2003; Evans and Schmalensee 2013; Hagiu 2009). Others argue that algorithms increasingly determine social and workplace outcomes, often in problematic ways (Pasquale 2015; Ajunwa and Greene 2019). Aneesh's (2009) research on a software firm that outsourced tasks to Indian programmers described its labor control as an "algocracy," (rule by algorithms) which is distinct from both markets and bureaucratic control. Platform researchers have made similar arguments, for example that ratings-triggered deactivation of drivers on ride-hailing apps represents a form of "algorithmic management" (Robinson 2017; Rosenblat and Stark 2016; Lee et al. 2015; Rosenblat 2018; Griesbach et al. 2019; Ivanova et al. 2018; Rahman 2016). Using online postings from Uber drivers, Rosenblat and Stark find that algorithmic management is facilitated via informational asymmetries. These include continuous data collection and surveillance via the app, the production of driver uncertainty about how surge pricing works, and the fact that drivers must accept rides blindly. They also argue that the algorithm achieves "soft control" via techniques such as gamification and behavioral nudges (see also Scheiber 2017). This approach posits enhanced management control, an informational Panopticon, high worker compliance, and a reduced zone of autonomy for earners. It emphasizes technological innovations and discontinuity with past labor management strategies.

While there is little doubt that technological developments have both enabled and structured platform firms, the algorithmic management approach can suffer from technological determinism. ${ }^{3}$ Algorithmic control involves human action and in the platform labor context is always paired with bureaucratic policy, such as the ratings cutoff for deactivation. Furthermore, as we and Attwood-Charles (2019b) argue, the power of the algorithm to control behavior and influence outcomes is variable across workers. In addition, there is a growing literature on worker resistance to and mastery of algorithms (Shapiro 2018; Chen 2018; Wood et al. 2019; Cameron 2018; Ivanova et al. 2018). Cameron (2020), in a departure from earlier more deterministic accounts, argues that ride-hail drivers have multiple ways of interacting with the algorithm (compliance, engagement, and deviance) and experience it as an opportunity to earn money and carve out zones of autonomy. Ivanova et al. (2018) make a different but related point, which is that while algorithmic management enables autonomy it can also paradoxically increase management control. This argument echoes earlier research, such as Michael Burawoy's finding that workers "consent" to their own work intensification (Burawoy 1979). Finally, both the precarity and algorithmic management approaches typically assume homogeneous outcomes for workers because the labor policies and forms of technological management are uniform within and across platforms. By contrast, we find marked differences across our respondents. For some earners, platform income mitigates precarity and algorithmic management is partially ignored. To support our claims, we turn now to our conceptualization of platform labor.

\section{A new analytic approach: platform dependence}

Our formulation rests on two aspects of the platform economy that scholars have not sufficiently emphasized - weak institutionalization of labor control, or what we term the "retreat from control," and the use of economic dependency to discipline labor. While the discourse about

\footnotetext{
${ }^{3}$ Exceptions come from ethnographic studies of digital labor, or crowdwork, which focus on social and cultural aspects of these global labor markets (Irani 2015b, 2015a; Gray et al. 2016).
} 
platforms frequently references issues of labor flexibility and autonomy, analysts have mostly been concerned about how much de facto flexibility workers have (Hall and Krueger 2018; Berg and Johnston 2019) rather than analytic implications of the absence of management control over scheduling and hours. We find that workers' right to choose their hours and schedules is central to what is innovative about platform work. Conventional firms generally exercise control over workers' hours, and variation is mainly across job type, rather than person (Altonji and Paxson 1988; Schor 1992). By contrast, among platform workers, there is high variation of hours within jobs. Hall and Krueger found that $51 \%$ of Uber drivers work 1-15 h per week, 30\% work 16$34 \mathrm{~h}, 12 \%$ work $35-49 \mathrm{~h}$ and $7 \%$ work more than $50 \mathrm{~h}$ (Hall and Krueger 2018). Robinson (2017) has similar findings for Boston drivers. A growing survey literature also finds a large number of earners with low hours per week hours and a small number with high hours (Manyika et al. 2016; Huws et al. 2017; Berg and Rani 2018; Forde et al. 2017). Platforms also cede control over many aspects of the labor process, in contrast to highly scripted service encounters in many low-wage jobs. Our research, as well as that of others, suggests that workers often choose platform work because there is no "boss," and they appreciate the scheduling flexibility and autonomy (Cameron 2020; Malin and Chandler 2017).

Platforms' willingness to accept providers irrespective of their other work commitments results in a more "situationally" diverse workforce than in conventional firms (Altonji and Paxson 1988; Schor 1992). This diversity is also manifest in a lack of common economic behaviors. Schor (2015) finds that platform workers do not conform to a single behavioral model, but differ based on whether or not they are income maximizers and the extent to which social and ethical considerations determine their actions. The existence of a diverse workforce also results in varied levels of economic dependency on platform earnings. Economic dependence functions as a disciplinary device for workers who do not have other income to rely on, and serves as an alternative to other methods of labor control. While economic dependence is also relevant in conventional workplaces, its analytic importance is heightened in this context because it is a key feature of diversity of situation, and by extension, workers' experiences. ${ }^{4}$

While scholars have recognized that the platform workforce is diverse in terms of hours and orientation (Robinson 2017; Ravenelle 2016; Malin and Chandler 2017; Rosenblat 2018; Manriquez 2019) the implications of this heterogeneity have not been adequately explored. One reason may be the Uber-centricity of previous research. Uber's size makes it an obvious object of study, but it is also unusual in that it has entered an industry with large economic rents and attracted unprecedented amounts of capital. Driving is a widely available skill, so the industry is prone to excess supplies of labor (Dubal 2017a, b). Over time, ride-hailing has attracted a higher percentage of full-time (dependent) earners than most platforms (Parrott and Reich 2018; UCLA Institute for Research on Labor and Employment 2018; Wells et al. 2019). It is also well-documented that Uber is a harsh manager. Journalistic accounts and qualitative studies of drivers provide evidence of poor working conditions, dissatisfaction, and even desperation (Paul 2019; Ravenelle 2019; Rosenblat 2018; Ladegaard et al. 2018). Some of these findings have contributed to a normative rather than analytic focus in the literature, with considerable attention to whether platforms are beneficial or exploitative for workers (Schor and Attwood-Charles 2017). Our data suggest that workers' experiences vary according to their

\footnotetext{
${ }^{4}$ Our analytic approach bears a family resemblance to economic models of efficiency wages (Bowles 1985; Schor and Bowles 1987; Shapiro and Stiglitz 1984), which focus on the economic rent available in the current job in comparison to the next best alternative, however the efficiency wage model does not take into account the adequacy of wages to finance living expenses.
} 
economic dependency, necessitating an approach that recognizes how the novel features of platforms yield heterogeneous outcomes.

A second insight is that the platform economy must be partially understood in relationship to the general labor market (Schor 2017). In the early days, we found that many providers opted for platform work because they were unable to find conventional employment in the wake of the Great Recession. Farrell and Greig (2017) find that the rate of growth of platform labor is influenced by conventional labor market conditions. The platform sector is nested within the larger labor market and trends in the availability and quality of jobs influence the experiences of platform workers. More specifically, the positive experiences of many platform workers are due to the benefits and security they simultaneously receive from their main employers, suggesting that platforms are free-riders.

\section{Methods}

As noted above, we believe a multi-platform design is best for developing theories of platform labor. We selected seven platforms (Airbnb, TaskRabbit, Uber, Lyft, Postmates, Favor and Turo (originally named RelayRides)) that conform to the Commerce Department's four criteria for "digital matching firms." These are 1) the use of information technology to facilitate peer-to-peer transactions, 2) crowdsourced ratings systems, 3) hours flexibility for workers, and 4) worker-provided tools and assets (Telles 2016, pp. 3-4). These criteria cover labor services as well as rental platforms such as Airbnb in which the bulk of the revenue is a rent or return to capital. While one may question the inclusion of Airbnb and Turo, we argue they should be included for two reasons. First, they share all the characteristics identified by the Commerce Department. Second, all platform services require some combination of labor and capital. Ride-hail drivers need cars, couriers use bicycles, and TaskRabbits sometimes need tools. None of our Airbnb hosts is a commercial entity, and most of them rented rooms rather than whole apartments. While Airbnb and Turo are outliers in one direction (high capital, low labor) their inclusion provides the kind of range that spurs analytic conceptualization. If we only focus on high labor, low capital platforms we run the risk of missing part of the range of outcomes.

We conducted 112 semi-structured interviews that were scheduled for $60 \mathrm{~min}$ although some went considerably longer. ${ }^{5}$ Almost all interviews were with people in the Boston area and were mostly done in person, although a few Airbnb and TaskRabbit interviews were conducted via Skype with people in other cities.

\footnotetext{
$\overline{{ }^{5} \text { Recruitment differed slightly by }}$ platform. In most cases we eliminated users who were outside our age range or did not have at least five trades on the platform. (The vast majority have done far more jobs/hostings, with some providers doing hundreds of jobs.) On TaskRabbit, we posted the interview as a task, which readily yielded informants. On Airbnb we queried providers via the platform, and once we made contact we let them know we were interested in interviewing them. The platform repeatedly deactivated our account when it realized that we were attempting to interview hosts. We created multiple accounts but eventually reverted to snowball sampling. On Postmates and Favor our researcher attended orientations and met people who he later attempted to interview. He also joined online fora (Facebook primarily) and recruited there. For Uber and Lyft we also tried to recruit via online groups but were unsuccessful. We ended up taking rides and asking our driver if he/she would be interested in an interview. We also attended meetings of drivers. We posted on Twitter and occasionally used Facebook ads to recruit, however these methods were unsuccessful. We started with a payment of $\$ 30$ per interview and raised it to $\$ 40$ over time.
} 
Respondents also completed a short survey about their earnings and demographic profiles. ${ }^{6}$ Interviews are concentrated among people aged 18-34 because this group constituted nearly all users when the research was begun and they continue to be overrepresented in the sector. ${ }^{7}$ Interviews began in 2013 with Airbnb, Turo, and TaskRabbit providers, and in 2015 and 2016 we added delivery and ride-hailing. In 2015, we conducted second interviews with nine providers from the earlier round. We are aware that our sampling strategy introduces a selection bias, because it does not include people who are no longer active on the platforms. However, because we are explaining the coexistence of satisfied and dissatisfied providers, rather than satisfaction levels, this bias is not disqualifying.

Here we offer a very brief description of each platform. Airbnb is a peer-to-peer housing exchange that offers whole home and shared listings, and uses online descriptions, and ratings and reviews to match guests and hosts. Turo is a peer-to-peer car rental service, akin to Airbnb for vehicles. TaskRabbit is a general labor services site on which customers hire "Taskers" to perform services such as housecleaning, deliveries, handyman work, pet care, moving, and furniture assembly, as well as online tasks such as being a virtual assistant or product tester, or doing translation. Uber and Lyft are ride-hailing platforms that match drivers to people who need rides. Our interviews were with drivers on the lower-priced UberX. Postmates and Favor are Uber-like delivery services that were originally envisioned as bicycle courier services offering a range of deliveries. They now specialize in delivering items from convenience stores, takeout from restaurants, and miscellaneous items from various retailers, and deliveries are carried out via a range of transportation options - bikes, cars, public transport, and walking, with bikes and cars predominating. ${ }^{8}$ We have amalgamated Uber and Lyft as one case, and Postmates and Favor as another because the services are so similar and because most of the providers we interviewed worked on both platforms simultaneously.

\section{Describing our respondents}

Descriptive statistics about our sample can be found in Table 1. The breakdown by case is 27 from Airbnb, 26 from Favor/Postmates, 11 from Turo, 31 TaskRabbits, and 17 drivers from Lyft/Uber. Some respondents are active on multiple platforms, for example Airbnb and TaskRabbit, and we have assigned each person to the platform they were more involved with or earned more from. As noted, our sample is young, with a mean age of 28.6. Our sample is a bit more than two-thirds male. While this is not surprising for delivery and driving, it is somewhat unexpected for the other apps. For

\footnotetext{
$\overline{{ }^{6} \text { The survey included a number }}$ of case specific questions as well as some open-ended questions, and respondents were free to answer as they liked. Case differences included the units in which earnings were measured, to conform to platform custom. This resulted in differences in how respondents interpreted questions so we have done some re-coding to create comparability across cases. Furthermore, as the project evolved we introduced some changes in the survey to reflect changing practice as well as some shifts in research questions.

${ }^{7}$ A Pew survey of gig labor platforms found that $42 \%$ were aged $18-29$ and another 39\% were in the $30-$ 49 year old range (PEW Research Center 2016).

${ }^{8}$ Favor subsequently left the Boston market.
} 
Airbnb it is partly because in some heterosexual host couples we interviewed the man. For TaskRabbit it may be due to a favorable labor market for women in Boston, given the preponderance of medical and educational institutions. With respect to race, $59 \%$ of our sample is white, with proportions African American, Latinx and Asian at 15\%, $12 \%$, and $8 \%$ respectively. Our sample is highly educated, with $21.5 \%$ holding graduate and $51.4 \%$ college degrees. Another $19.6 \%$ have completed some college and while there are a few college dropouts, most in this category are currently enrolled. Only $7.5 \%$ did not go beyond high school and just one person in the sample did not finish high school. Our demographics differ from some of the national surveys (PEW Research Center 2016), partly due to our location and because our age range is different, but mostly because we do not include crowd work, and we have a small driver sample. Table 1 also includes respondents' reported monthly earnings on all sharing economy platforms, broken down by case. We find that the largest two groups earn less than $\$ 500$ and $\$ 1500$ or more. Only four respondents, two of whom are Airbnb hosts, report earnings of more than $\$ 5000$ per month (not shown).

Platform experiences vary by the extent to which providers rely on the platform for their primary earnings. Based on answers to survey questions about what they use their money for as well as the interview data, we coded our respondents into three categories, shown in Table 2 . Dependent earners are those who are wholly or primarily dependent on the platform for their livelihoods. This group is roughly equivalent to full-time workers. The partially dependent group consists of those who rely to some extent on platform earnings, but either work on multiple platforms or have part-time jobs, small businesses, or other sources of income. Supplemental earners are those for whom the income is not part of their regular income, is not relied upon for basic expenses, and is considered extra. Many of the providers in this third category have full-time employment or activity (i.e., schooling). Using this categorization, we estimate that $25 \%$ of our sample are dependent on the platform, $42 \%$ are partially-dependent, and $33 \%$ are supplemental earners. The fraction of dependent earners in our sample is similar to other surveys in the United States and Europe (Berg and Rani 2018; Forde et al. 2017; Pesole et al. 2018; PEW Research Center 2016).

As expected, the distribution varies considerably by platform. None of our Airbnb or Turo respondents rely on this rental income as a primary source. More than half of the earners on both platforms are supplemental earners, and $40.7 \%$ and $45.5 \%$ respectively are partially-dependent. Among TaskRabbits, 25.8\% use the platform for supplemental income, $45.2 \%$ are partially-dependent and $29 \%$ are dependent. Postmates and Favor workers show a more equal distribution across the three levels of dependency, with $38.5 \%$ using their earnings as an income supplement, 34.6\% partially-dependent, and $26.9 \%$ fully-dependent. Drivers are much more dependent than earners on the other platforms, with $70.6 \%$ driving for a living, and $17.6 \%$ and $11.8 \%$ in the partiallydependent and supplemental categories. We have also calculated monthly earnings broken down by platform dependency, as shown in Table 3. As expected, those who use income as a supplement earn less, with 50\% in the under \$500 category. Among partial dependents, the largest group is in the middle income range. Finally, although $43.3 \%$ of those who are dependent on the platform for their primary income source earn $\$ 1500$ or more, a larger fraction take in less than $\$ 1500$ per month.

We find that platform dependency has strong relationships to both satisfaction and precarity. Those who are not dependent on the platforms have better experiences and 
Table 1 Descriptive statistics*

\begin{tabular}{|c|c|c|c|c|c|c|}
\hline & Airbnb & Turo & TaskRabbit & Favor \& Postmates & Uber \& Lyft & All Platforms \\
\hline \multicolumn{7}{|l|}{ Age } \\
\hline Mean Age & 28.3 & 29.5 & 29.6 & 25.5 & 31.6 & 28.6 \\
\hline \multicolumn{7}{|l|}{ Gender } \\
\hline Male & $\begin{array}{c}17 \\
(63.0 \%)\end{array}$ & $\begin{array}{c}8 \\
(72.7 \%)\end{array}$ & $\begin{array}{c}19 \\
(61.3 \%)\end{array}$ & $\begin{array}{c}19 \\
(73.1 \%)\end{array}$ & $\begin{array}{c}14 \\
(82.4 \%)\end{array}$ & $\begin{array}{c}77 \\
(68.8 \%)\end{array}$ \\
\hline Female & $\begin{array}{c}10 \\
(37.0 \%)\end{array}$ & $\begin{array}{c}3 \\
(27.3 \%)\end{array}$ & $\begin{array}{c}12 \\
(38.7 \%)\end{array}$ & $\begin{array}{c}7 \\
(26.9 \%)\end{array}$ & $\begin{array}{c}3 \\
(117.6 \%)\end{array}$ & $\begin{array}{c}35 \\
(31.2 \%)\end{array}$ \\
\hline \multicolumn{7}{|l|}{ Race } \\
\hline White & $\begin{array}{c}17 \\
(77.3 \%)\end{array}$ & $\begin{array}{c}6 \\
(75.0 \%)\end{array}$ & $\begin{array}{c}15 \\
(53.6 \%)\end{array}$ & $\begin{array}{c}16 \\
(61.5 \%)\end{array}$ & $\begin{array}{c}5 \\
(31.2 \%)\end{array}$ & $\begin{array}{c}59 \\
(59.0 \%)\end{array}$ \\
\hline African American & $\begin{array}{c}0 \\
(0.0 \%)\end{array}$ & $\begin{array}{c}0 \\
(0.0 \%)\end{array}$ & $\begin{array}{c}5 \\
(17.9 \%)\end{array}$ & $\begin{array}{c}5 \\
(19.2 \%)\end{array}$ & $\begin{array}{c}5 \\
(31.2 \%)\end{array}$ & $\begin{array}{c}15 \\
(15.0 \%)\end{array}$ \\
\hline Latinx & $\begin{array}{c}2 \\
(9.1 \%)\end{array}$ & $\begin{array}{c}0 \\
(0.0 \%)\end{array}$ & $\begin{array}{c}4 \\
(14.3 \%)\end{array}$ & $\begin{array}{c}2 \\
(7.7 \%)\end{array}$ & $\begin{array}{c}4 \\
(25.0 \%)\end{array}$ & $\begin{array}{c}12 \\
(12.0 \%)\end{array}$ \\
\hline Asian & $\begin{array}{c}2 \\
(9.1 \%)\end{array}$ & $\begin{array}{c}2 \\
(25.0 \%)\end{array}$ & $\begin{array}{c}2 \\
(7.1 \%)\end{array}$ & $\begin{array}{c}2 \\
(7.7 \%)\end{array}$ & $\begin{array}{c}0 \\
(0.0 \%)\end{array}$ & $\begin{array}{c}8 \\
(8.0 \%)\end{array}$ \\
\hline Other & $\begin{array}{c}1 \\
(4.5 \%)\end{array}$ & $\begin{array}{c}0 \\
(0.0 \%)\end{array}$ & $\begin{array}{c}2 \\
(7.1 \%)\end{array}$ & $\begin{array}{c}1 \\
(3.8 \%)\end{array}$ & $\begin{array}{c}2 \\
(12.5 \%)\end{array}$ & $\begin{array}{c}6 \\
(6.0 \%)\end{array}$ \\
\hline \multicolumn{7}{|l|}{ Education } \\
\hline High School or less & $\begin{array}{c}0 \\
(0.0 \%)\end{array}$ & $\begin{array}{c}0 \\
(0.0 \%)\end{array}$ & $\begin{array}{c}1 \\
(3.6 \%)\end{array}$ & $\begin{array}{c}3 \\
(11.5 \%)\end{array}$ & $\begin{array}{c}4 \\
(25.0 \%)\end{array}$ & $\begin{array}{c}8 \\
(7.5 \%)\end{array}$ \\
\hline Some College & $\begin{array}{c}1 \\
(3.7 \%)\end{array}$ & $\begin{array}{c}0 \\
(0.0 \%)\end{array}$ & $\begin{array}{c}7 \\
(25.0 \%)\end{array}$ & $\begin{array}{c}8 \\
(30.8 \%)\end{array}$ & $\begin{array}{c}5 \\
(31.2 \%)\end{array}$ & $\begin{array}{c}21 \\
(19.6 \%)\end{array}$ \\
\hline College & $\begin{array}{c}19 \\
(70.4 \%)\end{array}$ & $\begin{array}{c}3 \\
(30.0 \%)\end{array}$ & $\begin{array}{c}15 \\
(53.6 \%)\end{array}$ & $\begin{array}{c}12 \\
(46.2 \%)\end{array}$ & $\begin{array}{c}6 \\
(37.5 \%)\end{array}$ & $\begin{array}{c}55 \\
(51.4 \%)\end{array}$ \\
\hline Graduate Degree & $\begin{array}{c}7 \\
(25.9 \%)\end{array}$ & $\begin{array}{c}7 \\
(70.0 \%)\end{array}$ & $\begin{array}{c}5 \\
(17.9 \%)\end{array}$ & $\begin{array}{c}3 \\
(11.5 \%)\end{array}$ & $\begin{array}{c}1 \\
(6.2 \%)\end{array}$ & $\begin{array}{c}23 \\
(21.5 \%)\end{array}$ \\
\hline \multicolumn{7}{|l|}{ Monthly earnings } \\
\hline$\$ 499$ or less & $\begin{array}{c}4 \\
(18.2 \%)\end{array}$ & $\begin{array}{c}8 \\
(100.0 \%)\end{array}$ & $\begin{array}{c}9 \\
(36.0 \%)\end{array}$ & $\begin{array}{c}16 \\
(66.7 \%)\end{array}$ & $\begin{array}{c}1 \\
(7.1 \%)\end{array}$ & $\begin{array}{c}38 \\
(40.9 \%)\end{array}$ \\
\hline$\$ 500-\$ 1499$ & $\begin{array}{c}7 \\
(31.8 \%)\end{array}$ & $\begin{array}{c}0 \\
(0.0 \%)\end{array}$ & $\begin{array}{c}10 \\
(40.0 \%)\end{array}$ & $\begin{array}{c}7 \\
(29.2 \%)\end{array}$ & $\begin{array}{c}1 \\
(7.1 \%)\end{array}$ & $\begin{array}{c}25 \\
(26.9 \%)\end{array}$ \\
\hline$\$ 1500$ or more & $\begin{array}{c}11 \\
(50.0 \%)\end{array}$ & $\begin{array}{c}0 \\
(0.0 \%)\end{array}$ & $\begin{array}{c}6 \\
(24.0 \%)\end{array}$ & $\begin{array}{c}1 \\
(4.2 \%)\end{array}$ & $\begin{array}{c}12 \\
(85.7 \%)\end{array}$ & $\begin{array}{c}30 \\
(32.3 \%)\end{array}$ \\
\hline
\end{tabular}

*Column percentages reported for each variable

more control over when and how they work. They are more discriminating about whom they accept as customers, the amount of time they work, their conditions of work, and their schedules. They can more easily avoid exchanges they suspect will be unsafe or financially risky or will yield low earnings, or end up being negative experiences. These axes of control serve to enhance satisfaction, raise earnings, and ensure safer and 
Table 2 Platform dependence*

\begin{tabular}{cccc}
\hline & Supplemental & Partially dependent & Dependent \\
\hline Airbnb & 16 & 11 & 0 \\
& $(59.3 \%)$ & $(40.7 \%)$ & $(0.0 \%)$ \\
Turo & 6 & 5 & 0 \\
& $(54.5 \%)$ & $(45.5 \%)$ & $(0.0 \%)$ \\
TaskRabbit & 8 & 14 & 9 \\
& $(25.8 \%)$ & $(45.2 \%)$ & $(29.0 \%)$ \\
Favor \& Postmates & 10 & 9 & 7 \\
& $(38.5 \%)$ & $(34.6 \%)$ & $(26.9 \%)$ \\
Uber \& Lyft & 2 & 3 & 12 \\
& $(11.8 \%)$ & $(17.6 \%)$ & $(70.6 \%)$ \\
All platforms & 37 & 47 & 28 \\
& $(33.0 \%)$ & $(42.0 \%)$ & $(25.0 \%)$ \\
\hline
\end{tabular}

*Row percentages reported for each variable

more pleasant working conditions. By contrast, participants who rely on the platforms to pay their basic expenses feel more pressure to accept exchanges. They express more concern about their reputations and the ratings systems. They experience their situations as more precarious, although the extent of dissatisfaction varies by platform. Because both platform dependency and the specifics of the work vary across platforms, we have organized our findings by case. To avoid repetition we have interwoven the intermediate findings on partially-dependent earners into the two main categories. ${ }^{9}$

\section{Platform independence}

Airbnb providers are earning not mainly from their labor effort, but from the economic rents they can command from property they own or control via leases. They have valuable assets to rent and hosting does not require much labor effort, which results in strongly positive experiences. Hourly earnings are by far the highest across the sample, and work burdens are low. A large subset also reap a substantial non-pecuniary benefit from hosting - meeting and getting to know strangers. This is an appealing combination: high earnings, low work effort, and significant social benefit. Albert, a 33-year-old software worker, was drawn to the platform because "Well, it's good income, first of all, for not very hard work I would say." He also likes "meeting different people" and "having people around." To most of our participants, the least enjoyable aspect of

\footnotetext{
${ }^{9}$ Ravenelle (2019) groups respondents into three categories - success stories, strivers, and strugglers. The latter have affinities with our dependent earners - strugglers are financially precarious, experience sexual harassment, workplace injuries, threats to bodily safety, are cheated out of earnings by unscrupulous customers, and find themselves unwittingly drawn into criminal acts such as drug dealing, prostitution, or violence. Only a few of these outcomes surfaced in our data. Ravenelle does not provide estimates on the numerical breakdown of her sample, so we cannot be confident that her outcomes are overall more negative, but they seem to be.
} 
Table 3 Platform dependence by platform earnings *

\begin{tabular}{lccc}
\hline & Supplemental & Partially dependent & Dependent \\
\hline $\begin{array}{l}\text { Monthly earnings } \\
\text { \$499 or less }\end{array}$ & 19 & 13 & 6 \\
& $(50.0 \%)$ & $(34.2 \%)$ & $(15.8 \%)$ \\
$\$ 500-\$ 1499$ & 8 & 14 & 3 \\
& $(32.0 \%)$ & $(56.0 \%)$ & $(12.0 \%)$ \\
$\$ 1500$ or more & 5 & 12 & $(43.3 \%)$ \\
\hline
\end{tabular}

*Row percentages reported for each variable

hosting is the cleaning - but even this is seen as a simple task. One host reports that cleaning is "fairly easy. We had like a washer machine in the apartment, and so we just changed the sheets, washed them, and good to go. ... I guess I don't mind doing it, and in some ways it's simpler than dealing with [a professional cleaner] and scheduling them especially if it's like every two or three days or whatever." Even among those who are partially dependent on the platform to help pay rent, the effort bargain is attractive. Dennis and his wife began hosting to earn some extra money and because "life is expensive here.... Someone, you know, sleeps in the bedroom for a couple days, and you got a couple hundred bucks. So, good deal.... Like, oh this is really easy, you don't have to do much. People just want to be kind of left alone most of the time and so do we."

Some of the most satisfied hosts we talked to live in Cambridge, where there is strong demand from guests who are highly educated and highly employed, often attending academic conferences or graduations. Karen, a 33-year-old Harvard researcher, had friends renting space in her home for "next to nothing" until she discovered Airbnb. She now has dozens of guests every year, has hired a professional cleaner, and makes about $\$ 2500$ a month.

I honestly think it was within five minutes [after creating a profile], somebody booked the room for 10 days. It was $\$ 1000$ within two seconds. A really amazing woman from Japan was coming to visit her daughter who was graduating from Harvard. And so it's sort of been like that ever since, where there are definitely lulls. I mean, you're not going to get rentals really between November and March.... But from March to November, you can.

Turo owners earn much less than Airbnb hosts, but report similarly positive experiences. Will, a political operative whose expensive car sits idle while he travels, reports that "the juice is worth the squeeze." He loves that his car is no longer a drain on his finances, and has become an income-earning asset. He is able to mitigate risk by refusing potential renters he considers "sketchy." Nathaniel, who rents out on both Airbnb and Turo explains that part of his comfort with the exchanges is his limited downside risk. He does not rely on his car to get to work, and the Airbnb property is a 
family vacation home. He is not dependent on this income, plus he gets peace of mind from the platform-provided insurance. "I feel like I'm equipped to deal with it and it won't be a big deal. So if I was reliant on my car to get to work every day, or if my financial situation was such that, you know, could put me in a really bad position if something happened, then I would probably be a lot less likely to use the service."

Rather than creating precarity, as we find on other platforms, Airbnb and Turo add to respondents' economic security and sense of agency and enable lifestyles that they could not otherwise afford. Thirty-year-old Hannah moved into the expensive Beacon Hill neighborhood, "which I didn't think I could even live in on a teacher's salary because it's like a joke in Boston." For Charvak, who earns in the six figures, Turo income financed a high-mileage hybrid vehicle he bought to make long car trips cheaper and greener. A number of our hosts are using their earnings to pay off educational debt, finance luxury spending (such as a spectacular wedding), or travel.

TaskRabbit providers who have other jobs and use the platform for supplemental income also report high satisfaction. They like the flexibility, control, and high hourly wages they can earn. In one national survey (PEW Research Center 2016), 42\% of gig workers reported they work on platforms "for fun or to do something in [my] spare time." Many of our Taskers note the appeal of using their time off work "productively," explaining that they are otherwise bored. Even those who did "personal organizing" or "house cleaning" explained that they enjoyed the work. Earning money under these circumstances is a boon. Members of this group tend to have flexible schedules, low living costs, and are more likely to be students. Lenny is a 28-year-old Chinese American graduate student in social work who earned roughly $\$ 750$ per month over his 4 months on TaskRabbit. He regarded his earnings as "kind of like a safety net income, I guess" and stressed, like many, the flexibility of the platform. Even though Lenny's skill set is not particularly specialized, he can wait for higher paying, more convenient tasks. TaskRabbit has replaced the income he earned from a catering job that was an "undesirable position" where managers treated workers poorly. For people like Lenny, platform labor is an alternative to low-end work in the conventional economy, rather than spurring a race to the bottom.

The ability to be discriminating about tasks also matters for Ernest, a 26-year-old African American mechanical engineering student who earns most of his income driving for an upscale furniture store. Ernest is able to vary his hourly rate by the desirability of the task, earning from a low of $\$ 75$, to $\$ 150$ for tasks he does not like such as standing in line. He reports being "really picky" about tasks, and only does about three per month. Ernest is able to charge high wages because he does not need the work. He likes heavy lifting because "nothing can go wrong with the heavy lifting" and he often finishes the task in $30 \mathrm{~min}$, but is paid for the full hour. Other providers also tell us they have learned to pick up tasks they know will take much less time than advertised (such as snow-shoveling), thereby yielding high hourly rates. Diversification is another strategy for non-dependent workers. Maria optimizes her labor across a parttime hotel job (which gives her benefits), TaskRabbit, and Uber. A 38-year-old immigrant from Brazil with only a high school education, Maria reduced her hours at the hotel after a divorce in order to accommodate her children's schedules. When we interviewed her, she was working $40 \mathrm{~h}$ a week driving for Uber, grossing \$50 an hour. However, because she is responsible for expenses with Uber, she prefers $\$ 35$ on TaskRabbit. Eventually Maria was able to raise her hourly housecleaning rates to 
\$39 and \$50 (for basic and deep cleaning), and likes the fact that once a task is booked, she will definitely be paid for it, unlike with Uber where low demand may reduce earnings. We find that some Taskers, especially those with longer histories on the platform, build stellar reputations via large numbers of successful tasks, putting them in a position to command high rates. They are helped by the platform's algorithm, which pushes "elite" or "lead" Taskers to the top of the list, where customers see them first. Christopher is a 24-year-old Haitian American with a bachelor's degree from Harvard who earns $\$ 3500$ per month on TaskRabbit, in addition to having a full-time, but flexible Emergency Medical Technician job. Christopher has been active on the site for years and has done more than 500 tasks. He tends not to maximize his hourly rate, but prefers to get more work. However, his rate is high $-\$ 60$ per hour for physical labor jobs - and he explains that he has "so many reviews at this point, like, if someone doesn't want to hire me at the price that I set it at then, like, I'm not going to feel bad." Similarly, Mark, for whom managing Airbnb apartments is his main source of income, says he has "learned how to really push, really push up my rates" by completing many jobs and earning positive reviews.

Part-time or casual drivers on ride-hailing apps who are supplementing a main source of income report similarly positive experiences. They feel liberated from the nine-to-five work structure, and perhaps more than anything else, like that they don't have to report to a boss. They are enthusiastic about the software that creates novel economic opportunities and enables strangers to connect in an environment of trust. Nathan says Uber is "probably the best thing ever," because he now has an easy and convenient way to make extra cash, for example, when he picks up passengers on the commute to his full-time job or when he has some spare time. "When I'm bored, instead of playing videogames I just turn on the app, wait for a ride and just go on my hustle." He is not earning as much in his full-time job as he would like and feels he is not saving enough for retirement because his employer does not give a $401 \mathrm{~K}$ match, so he is putting his Uber earnings into a retirement account. Twenty-eight-year-old Bobby, who is white and works as a digital media instructor in a public school while also pursuing an MA in education, has used ride-hailing as a means to supplement the income from his teaching job and to reduce commuting expenses. He says that he drives 6 to $10 \mathrm{~h}$ a week, depending on "where I am financially" and if "I want to do specific things that are going to cost more money." The weekend before the interview he "ran like straight out of money on a Friday," so he drove some hours to pay for concert tickets.

More than a third of the couriers on Postmates and Favor are supplemental earners. Tamara was an African American woman in her late twenties who regaled our interviewer with stories of thrift. Tamara came from a military family, married a plumber, and moved from the South to Boston to work as a special education assistant. She and her husband had a young baby and were trying to create a stable middle-class life for themselves. While Tamara did not make much in her regular job, she prided herself on being resourceful. She began making deliveries as a Postmates courier, which she liked because the baby slept well in the car. As she put it:

My husband and I, we're really, we're kind of entrepreneurs ourselves. He actually just started an Airbnb thing... We are subletting in our house, 
and then we are running two other houses. So we're on Craigslist a lot, and I saw it on Craigslist about a year ago, and I was like, hey, I think I will give this a try. He was like, well, yeah we could kind of use the money. I was like, well, I mean, it's something I can take a little one with me while you are at work or you're late. I was like; it's something we don't really have to worry about.

Tamara did not feel pressure to accept jobs she didn't want to take, and didn't hesitate to speak up when she thought a customer was being unreasonable. Asked about safety concerns, she explained: "I don't feel any. I like it [Postmates] because I don't have to go in their house, and that's a perk for me. Then plus, when it gets dark out, I don't get out of the car. I make them come down and get it. Which, I love being able to do that." Tamara provides an example of how a supplemental earner can afford to risk low customer ratings and violate company policy (by not getting out of the car) to reduce risks and achieve job satisfaction.

Chris was an undergraduate at a local university who occasionally worked on Postmates when surge pricing was in effect and the premium made it worth his while. He didn't depend on Postmates for an income, stating, "Most of it goes towards student loans or car payments. And some of it's for recreation." He liked that it allowed him to be noncommittal, being on the app only when he wanted to. Chris enjoyed listening to fantasy football and driving, which fit well with the work. He thought that Postmates paid well, even if they did not pay what was advertised. Because the income is supplemental for him, Chris also has the luxury of being unconcerned about how ratings are determined and how the system allocates work. When asked if he ever worried about his rating, he replied: "I have a 4.9 and I'm, like, what they would call an 'awful worker.' Like, they give you these food bags to keep the food fresh, and these stickers that you put on the bag that say, like, 'Have a nice day.' I, like, don't use my food bag unless it's going to be more than 20 minutes." Because of his situation, Chris was unconcerned about violating company policy concerning food bags and stickers. Michelle, a Japanese American woman in her late-twenties, worked as a software engineer before quitting to "explore music as a hobby" at the Berklee College of Music. She was quick to point out that she did not need the income, stating that she only joined the platform because she met a courier outside her apartment who said if she attended an orientation and provided his name, he would receive a promotion. Michelle's discretionary approach is revealed by the way she earmarked her earnings. "I think of it as going towards food expenses, because I'm delivering food. And it's not really that much, you know?" In general, delivery providers who do not need the income avoided the undesirable aspects of the work. They did not feel pressure to work during disagreeable hours, accept difficult orders, or hesitate to say "no" to a task or customer out of fear about the impact on their rating. They expressed greater satisfaction with the pay than couriers whose earnings were used for basic expenses.

\section{Precarity and dependence}

Our findings are markedly different for dependent providers from those for providers who use the platforms to supplement full-time earnings. Many dependent providers 
also enjoy the work or prefer it to their existing alternatives, as we would expect given that they remain active on the platforms. However, they are far less satisfied, report less flexibility, and have less freedom to hold out for higher wages than their non-dependent counterparts. Their situations are more precarious, particularly if they do not have housing from parents or spousal incomes to rely on. Among the Taskers, nine are attempting to earn full-time on the platform. Some were recent college graduates, hoping to land regular jobs. They were more sanguine about their experiences, and their dissatisfaction related more to the labor market than their treatment on the platform. However, a number of them were interviewed in the early period, a time when providers felt the platform "had their back," which a number of respondents felt was no longer the case after the platform abandoned its auction model in 2014 for less variable rates. Providers further removed from college, or who had experienced job loss, were not so positive. Derek lost a $\$ 200,000$ a year job and has been unable to find new employment in software, picking up jobs on TaskRabbit and Craigslist. He also finds off-platform work through contacts he meets on TaskRabbit, which he considers a great benefit of the platform and he did discuss some lucrative tasks. However, he also expressed considerable bitterness. He described a day when he had no other work, so he picked up a delivery job that in the end yielded only $\$ 10$ an hour and was "the stupidest thing I ever did.... I mean like there are many times that you do this and you think, I'd be way better off working at McDonalds because I'd make the same amount of money and I'd have free fries."

Julian, a single white 32-year-old male, is also articulate about the pitfalls of relying on the platform. With TaskRabbit, it is "actually really a race to the bottom." He reports that one poster told him "it's almost exploitative the things she can get people to do for \$10." Julian was trying to be an entrepreneur, selling and writing about software. He had lost a full-time job as a surgical technician, and along with it his home. So he sold all his possessions and bought a membership in a co-working space that offered Internet and some free food. He tried to hide his homelessness by running to the coworking space every morning so that it looked like he needed a shower because of his exercise routine, rather than his homelessness. "It's absolutely mentally exhausting to keep up all these projects and this farce about my living situation." At the time of the interview, he'd earned only $\$ 4500$ on the platform. Julian discussed his situation in frightening terms: “It's like I'm going to die because I'm not going to buy food, or I'm going to freeze to death in the wintertime.... I made it work though." But he saw his situation as temporary. He was learning a programming language that he felt confident would guarantee him a job and $\$ 80,000$ a year. "So it's really going to be a 180 for me to go from, like, hustling around and doing TaskRabbits for 25 dollars to being really employable and having a really valuable skillset." At the same time, he really enjoys a lot of the work, finds it "pleasurable" and rates the platform a "10."

While our respondents mentioned race to the bottom a number of times, the platform's switch away from the auction model raised hourly wages, and many Taskers can find jobs at good rates. Racquel reports her personal wage floor is $\$ 25$ per hour. Another Tasker reports a $\$ 17$ per hour wage. But the higher wages that have prevailed since mid-2014 are likely a key factor explaining why demand is not more robust, and they must be seen in the context of low total earnings. (The company also increased its first time service fee, which is folded into the cost, to a hefty $30 \%$. Taskers complained that clients do not know the company takes that portion.) Racquel's $\$ 25$ per hour was 
only yielding her about $\$ 10,000$ the year of her first interview. Derek is earning $\$ 12,000-20,000$ a year. Our experience trying to do ethnographic research on the platform bears out the lack of demand-while it was easy to sign up, over a period of months our researcher was unable to get any tasks. As Derek explains: "Working for TaskRabbit is just a fantastic way to always stay at the poverty level, right? But at least you can pay your phone bill and you can buy some food and the landlord isn't upset with you." We also found evidence of deteriorating provider conditions on the platform. A number of our early respondents stopped participating. Among those who stayed active for a while, ratings of the experience dropped sharply. "They used to really, like, I don't want to say fight for us, but they were definitely like more responsive, I should say... Most TaskRabbits feel that way though, it's not just me." Another explained that the company used to care about the individual rabbits, but no longer does." A third went farther: "We really are just cannon fodder.... They don't really care about us."

Some of the dependent providers were able to make it work, but a number of them live with their parents. Mark, a white 24-year old, is an evening college student who does tasks during the day and earns about $\$ 25$ per hour. He puts $20 \%$ of his earnings into savings and the rest is for his personal expenses, which mostly includes transportation and eating out. He takes the 6:30 AM train to the major urban area and then works until he takes the train back for evening classes. Since he is already committed to spending the day working, Mark places his wages below the average price for a given task so that he can fill his day with work. He is not comfortable with some tasks, like building IKEA furniture, and does not own a car to do deliveries, so he relies heavily on the "quick assign" market. (Quick assign is when a purchaser does not select the Tasker but puts out a request and the first Tasker to accept the job wins it.) Mark also feels he needs to take almost every task he can. He has lost the much-vaunted temporal flexibility of the platforms and has adopted the regular early commute and full day of work. He has also lost the ability to choose or to set a good rate, because he needs to underbid for tasks in order to get enough work.

Similarly, dependent delivery couriers accept nearly every request. It was not uncommon for these participants to work on multiple courier platforms simultaneously, waiting in their car or on their bike for one of their apps to come through with a job. Favor was preferred by these couriers, as it offered an hourly guarantee, unlike Postmates, where respondents reported waiting for hours without receiving a request or earning anything at all. But Favor shifts are limited, and tended to go fast. There's also a downside to Favor's wage guarantee, which is that couriers cannot turn down deliveries without incurring a penalty. This means that they must take jobs they know or suspect will be problematic for one reason or another. This becomes especially difficult if they also add a Postmates shift for hours they have already committed to Favor. This was worth doing because Postmates gives algorithmic priority to people who reserve shifts in advance rather than to those who just turn on the app. However, none of our respondents knew how much that priority actually helped. But simultaneously committing to both apps also increased the likelihood of penalties on Favor.

All of our dependent respondents articulated critiques of their situations and felt it was a less-than-ideal working arrangement. However, many felt they had no other options. Some had lost conventional jobs or were unable to find work. Others were shut out of other platforms. Ervin, an African American man in his late twenties, had 
worked for Uber before signing up with Favor, but was deactivated when Uber changed the minimum model requirements for its drivers. He had moved to Boston from Oakland, California to attend graduate school for social work. Ervin described himself as "lower class," and when asked how he settled on Favor, replied, "So I needed the money and I have a car. I actually was doing Uber before, but my car is too old. I have a 2000 or 2001. They changed their policies.... The money [on Uber] was better than Favor, yeah." Ervin had just graduated but was struggling to find work and was desperately trying to save enough money to move to Philadelphia. As the interview progressed, he appeared increasingly overwhelmed. When asked what he needed the money for, Ervin said, "Saving to move, my credit card bill, car repair because I need to get that in the shop, so yeah. I've been kinda, you know, not knowing because I know it's gonna be expensive. All I know is it's only gonna get worse. But it's like, do I keep my car and risk it getting worse or do I take it in now and take this huge financial blow?" Ervin's one asset, besides his graduate degree (which was not paying off at this time) was breaking down when he needed it the most. Another courier, Charles, came from an impoverished town, had a criminal record, and found getting steady work very difficult. He was hoping to start college eventually with the dream of becoming a therapist, but for now, he was taking the bus from Connecticut to sleep in his brother's dorm room. Charles was only able to work in spurts, as his scooter would break down and, in the winter, he would have to find a car. One day, on an online courier group, it was announced that Charles won $\$ 100$ for his excellent customer service. He was delivering a lunch order when he was rear-ended in traffic. Although he complained of whiplash, the post proclaimed that Charles nonetheless completed the order in the time allotted. By the logic of the platform, it was his lucky break, but in terms of physical well-being, he felt compelled to keep working immediately after an accident, foregoing needed medical attention.

Erratic earnings are another problem. While supplemental earners are able to turn off their apps when business is slow, traffic is bad, or weather is forbidding, dependents find themselves locked into undesirable situations. For drivers and deliverers this can be because they have to front money for a vehicle. This was the case for Horatio, a courier who did not own a car. At times, he would take advantage of Zipcar promotions, explaining that any money was better than no money, regardless of the razor thin margin.

I don't have to pay for gas with a Zipcar. Because you pay $\$ 30.00$ Monday through Thursday if you get the car from 6 p.m. to 8 a.m., so with Favor you could have probably a good four or five hours, so if you make at least the $\$ 30$ within the first two hours, then the rest of it is profit. It depends. Sometimes you get better nights than others, sometimes it's worth it and sometimes it's not.

Despite having a bachelor's degree in business, Horatio was unable to find full-time work and was cobbling together an income on various delivery platforms. He seemed genuinely at a loss in terms of what he should be doing. He was tired and lacked optimism about his future. Daria, a white woman in her early twenties, came from a poor family and seemed to be constantly on the move. She described her dad as a "deadbeat," and was not in contact with her mother. After following an ex-boyfriend to 
Boston, Daria looked for work that would keep her from having to live on the streets, and she found it at a downtown convenience store making breakfast sandwiches for construction workers. This was not enough to cover rent, so she began looking for additional work and stumbled across Favor. While it gave her an opportunity to earn some extra money, it was a grueling schedule. As Daria recalled:

I would bug my boss at the convenience store for the schedule to be on time please for that week and then as soon I had that I would put every hour that I wasn't working at the convenience into my like Favor availability and then I'd just like work all the time. I would do like weird hours at the store. I'm like not really much of a morning person. So I would start Favor when they opened, which I think changed from like 11:00-10:00 or like 11:00-9:00 or 10:00-9:00, something like that. It got earlier during the time I was working there and I would just take first shifts and then I would go over to the convenience store like 2:00 and work from 2:00 until 10:00 and then I would go back to Favor from like 10:00 until midnight or 10:00 until 1:00 or whatever, depending on the day.

Eventually Daria began to work full-time as a courier, first for Favor, and then for a local non-platform courier company, which paid better and was more consistent. Like Horatio, Daria seemed tired, fatalistic, and resigned to a future of low-wage, unsteady work.

Twelve of the seventeen Uber and Lyft drivers we interviewed are dependent on the platform. Dependence undermines the flexibility and autonomy that ride-hailing companies tout and many drivers desire. Respondents who have resisted full-time driving were especially articulate at explaining why. Thomas, a 27-year-old Uber driver is partially dependent, earning about $\$ 12,000$ a year from the platforms. He says it is "impossible" to have a decent hourly wage if you simply drive whenever you want. "So in order to be a fulltime driver and make a living wage you have to drive every rush hour." To match the hourly wage of a bus driver, he has to catch the rush both in the morning and in the afternoon, and ideally also be on the road as early as five in the morning, when there is substantial airport traffic. Forty-one-year-old Alice, who has two children and drives between 15 and $30 \mathrm{~h}$ a week to boost her family's household income resembles Thomas in that she is unwilling to drive full-time but feels compelled to drive when the demand is high.

Maybe 1:00, and then I know it's busy, and then I maybe stop for a little bit and go back out at 5:00 when there is rush hour. Then again in the nighttime, there might be a game and I take everyone to the game. Then after the game I'm out there again, you know. ... I'm a hustler, you know. I'm a very hard working person. It's just me. Because everyone, we all like, we have bills, and we all like, we like nice things. We all want better things in life, so yeah, sometimes I, I starve myself. I'll just eat later, you know. It's not the best thing to do, but if it's busy, and I'm needed on the road I'm going to be on the road you know. I don't think I'm going to starve myself to death, you know. Eventually I will get something to eat.... It's like, why work from 1:00 [to 3:00] PM for half the price when you know, I can work from 3:00 to 5:00 and make double the money in less time. You know? 
Our respondents explain that the workday of a driver has a substantial vacuum of activity in the middle of the day and the lost income will have to be recouped by driving when the app tells them there is demand. In many cases, that means that they feel compelled to work outside of the conventional office hours, e.g., weekends and late evenings. Rather than freeing up time for family and social leisure activities, drivers have little business when everyone else is at work, and more when everyone else is free. Changing conditions also lead to added precarity and anxiety. Drivers report that platform rules and rates are in continual flux and that they cannot rely on conditions at any point in time. Many of our participants are anxious about the direction the platform is going, in large part because they feel powerless about the changes. Drivers might not have a boss who tells them what to do, but they are constrained by the platform's measuring stick and the threat of sanctions. Boris, 33, has been driving for Uber for several years and is currently leasing a few cars to other drivers. He suggests these jobs are precarious.

Uber ... kind of force people to.... They say that there is no ... need to stay online on certain hours unless you want to. But then, if you are online and you don't accept certain trips, basically your acceptance rates go down.... And they require like at least, what, $95 \%$ acceptance rate. And then when you go lower than 95 acceptance rate, you have a chance of being deactivated.... And that goes not only by acceptance rates as well as like by canceling the trips. Although they are saying like you have a full right to cancel the trip... So, whenever the time comes, they will have an excess of drivers or they will need to get rid of some bad drivers ... they hold their right to cancel you.

Boris says that drivers are also squeezed by top-down decisions that hit everyone, regardless of their ratings and scores.

I mean, you're kind of limited to those rules that are set by Uber. And then you're looking right in terms of the profits. And then, on top of all that, the rate can be decreased at any time without any explanation ... [if] you figured, like, okay, here it is, $\$ 1.50$ a mile [for gas], and I think I can make money out of it, you went on and bought a brand-new Prius.... And then when you put all this stuff together and you have a great tool to operate, and then ... the rate cuts half, you're like, what should I do? The only thing left is just to cry and say, like, oh, these are bad guys.

\section{Variation across the platforms: a vertical hierarchy}

We find that outcomes vary by platform, a finding also noted by Ravenelle (2019). We summarize our findings in Fig. 1. While much of the literature has treated the sector as a monolith we argue it is better understood as a vertical hierarchy in which some platforms are better to work on because they yield higher earnings and have better conditions. In this way, the sector is similar to the conventional labor market. This 
hierarchy is largely determined by requirements for participation. The first is capital requirements for participation. Airbnb requires access to an apartment, either via ownership or lease. In addition, the location of the property determines its ability to attract guests. Hosts who live in neighborhoods that are whiter, higher income, and with more highly-educated residents are more likely to earn successfully on the platform. (Cansoy and Schor 2019). Turo requires only a vehicle to participate, although we found very high educational and professional attainment among that group. TaskRabbit appears to have an informal educational requirement of either a college degree or at least college enrollment. In addition, nearly a quarter of Taskers have graduate degrees. This platform yields much higher wages than those that specialize in delivery or driving, so lack of formal education is likely functioning as a barrier to high earnings. One reason may be that customers are themselves highly educated and prefer to hire others of their educational class, even for manual or low skilled work, such as housecleaning or moving. Driving and delivery platforms require less in the way of assets. Driving apps only require a car of relatively recent vintage, although both Uber and Lyft offer deals for low lease rates, but only if drivers satisfy a quota of weekly rides. Delivery apps can be joined with no physical assets or education.

While we do not have accurate hourly wages to compare remuneration structures, our data do show a rough ordering across the platforms that matches the asset requirements. Airbnb yields the highest earnings, with our hosts mostly earning in the $\$ 100$ per night range. Some earn less, and the high in our sample is $\$ 350$ per night, with variation by desirability of the property and whether the rental is an entire apartment or a room within a unit. Turo earnings are not high, but they require almost no effort, yielding an excellent hourly return. TaskRabbit wages are generally above $\$ 25$ an hour, and can range to more than $\$ 100$. We do not have good data on net hourly earnings from drivers, in part because of the need to subtract expenses, which not all drivers do, as well as the complex bonus structures now in place. Robinson (2017) suggests net hourly earnings can be as low as $\$ 7.50$, a figure that accords with other studies, although many drivers earn more. Favor couriers could sometimes secure a $\$ 15$ per hour guarantee, but on Postmates the rate is often less, with workers reporting hourly wages as low as $\$ 8$ per hour, without accounting for waiting time. Airbnb hosts face the lowest levels of threat, although one was sued by his condo board and another, who could not afford his apartment without hosting, was forced to stop by other building residents. Taskers experience precarity of earnings, but have more control over their work than drivers or couriers. Drivers are experiencing declining levels of autonomy and control and increasing competition for business. Couriers who are not platform-dependent are able to retain control and autonomy but dependent earners are often desperate.

The platform hierarchy also roughly correlates with the fraction of dependent workers. Airbnb and Turo have the fewest dependent earners, ride-hail has the most. This raises the question of whether dependence on the platform is a proxy for socioeconomic status, which itself is the cause of more negative platform experiences, rather than dependence itself. Our sample is too small within each platform to be able to answer this question. However, our respondents have very high levels of education overall, even on the less remunerative platforms. Some of our most dependent and desperate earners previously had thriving high income careers and marketable skills or are training for lucrative careers. Most are not low SES in conventional terms. In 


\begin{tabular}{|c|c|c|}
\hline Asset requirements & Wages and earnings & $\begin{array}{c}\text { \% Supplemental } \\
\text { Earners }\end{array}$ \\
\hline Airbnb & Airbnb & Airbnb \\
TaskRabbit & TaskRabbit & Turo \\
Turo & Turo & TaskRabbit \\
Uber \& Lyft & $\begin{array}{c}\text { Uber \& Lyft } \\
\text { Favor \& } \\
\text { Fostmates }\end{array}$ & Favor \& Postmates \\
Favor \& Postmates & Uber \& Lyft \\
\hline
\end{tabular}

Fig. 1 Platform hierarchy

addition, even if dependency is highly correlated with socio-economic status, the results show that even with an identical technology and set of workplace rules, outcomes vary, in contrast to more optimistic views that digital technology will be a great leveler.

\section{Technology and labor}

Analyses of platform labor should ultimately be nested within the larger landscape of technology labor. There is now an expansive and illuminating literature on work in this sector, from Andrew Ross's early account of high tech workplaces (Ross 2004) and Gina Neff's description of "venture labor" that may or may not be remunerated (Neff 2012), to more recent expositions, such as Gray and Suri's pioneering treatment of global crowd workers (Gray and Suri 2019). A number of observers have produced typologies of types of work in the platform economy (Kenney and Zysman 2019; Vallas and Schor 2020). One observation from this literature is that the kinds of work that are now provided through platforms has expanded rapidly-from well-known services such as driving and image tagging, to caring labor, artistic production, athletic coaching, long distance teaching, legal services, and telemedicine. Differences across these types include the level of skill, the spatial dispersion of the work (Vallas and Schor 2020) and the nature of the employment relation. There are highly skilled platform architects and designers, most of whom are extremely well compensated employees for whom companies have been competing fiercely. At the other end of the spectrum are gig workers who possess only generalized skills (e.g., driving, housecleaning) and are independent contractors with little market power. This group is divided into those who work in the cloud and are spatially dispersed and those in the faceto-face service provisioning segment also referred to as the "sharing economy" (see Schor 2020 on terminology). Kenney and Zysman (2019) use a more expansive categorizationplatform mediated work. This includes in-person gig labor, marketplaces such as Amazon and etsy that service independent businesses, and remote service provision for discrete digital projects on platforms such as Upwork, Fiverr, and Amazon Mechanical Turk. The latter category ranges from the very poorly paid (e.g., AMT) to higher skilled graphic design and coding (Upwork). Kenney and Zysman also include an additional class of platformmediated content creators, which includes Instagram and You Tube influencers and content providers, only some of whom earn anything at all. A key feature of most of the types of platform work discussed above is that the distributions of work and income tend to be bi- 
modal and markets are often winner-take-all. For example, while most Uber drivers work few hours, a portion of long-hours drivers do the majority of the rides. There are similar distributions among Upworkers (Popiel 2017), etsy sellers (Etsy 2013), content providers, and crowd workers. In our research on a platform cooperative for stock photographers we found a highly skewed distribution in which the top $1 \%$ of earners received more than a quarter of the site's revenue (Schor 2020). Indeed, this is a general feature of platforms in which there is open employment. Another important finding in this literature is the extent to which human management remains important, even in the most digitized or algorithmicallymanaged applications. Shestakofsy's (2017) ethnography of a matching platform for household services found high complementarity between human and machine functions; Irani (2015a) and Gray and Suri (2019) also find that behind the growing capabilities of Artificial Intelligence are millions of human decisions and hours of labor. Attwood-Charles (AttwoodCharles 2019b) finds that app-based delivery workers often get calls from human managers. This brief discussion barely scratches the surface of this rich literature, which includes important new contributions elsewhere in this special issue. But it serves as a reminder of a crucial insight for studying gig labor made some years ago by Kenney and Zysman (2016): to understand any segment of the platform economy (such as the gig labor segment addressed in this article), we must situate it within the larger context of the technology platforms and their ongoing re-organization of economic activity and life.

\section{Conclusion}

We have emphasized the importance of platform dependency, as well as variation across platforms as key axes of differentiation in the sharing economy. Our findings suggest that access to alternative sources of income and security are almost a precondition to achieve satisfying experiences for workers. This implies that platforms are free-riding on conventional employers, who provide the security and stability to make platform labor desirable. These findings highlight the need to study those who exit the platforms. We also believe our findings would be strengthened by testing the robustness of our findings with a large-scale survey. Another important issue is the trajectory of platforms. In addition to questions of institutionalization, there is strong evidence of declining conditions on the ride-sourcing platforms as they cut rates and increase control (Schor 2020). Another unexplored but important dynamic in the platform sector is its role in exacerbating inequality. The high education levels of providers, coupled with the predominance of supplemental earners suggests that platforms have been facilitating a new kind of opportunity-hoarding by the more privileged segments of the middle class (Schor 2017). We find that the novelty of these apps has reduced the stigma associated with manual tasks such as driving, housecleaning, and delivery and has induced many highly educated people to take on this work. In the current era of downward economic mobility, this is not surprising. But it does suggest an even more complex situation for those interested in constructing an equitable labor market.

A persistent theme in the critical literature is the fear that platforms are inducing a race to the bottom, which will end in worker exploitation and misery (Ravenelle 2019; Rosenblat 2018; Scholz 2016; Dubal 2017b). Recent regulatory efforts to classify gig workers as employees, such as California's Assembly Bill \#5, passed in 2019, may presage a wave of reclassification, although company resistance and non-compliance 
remain potent. Whatever the outcome of that fight, our findings suggest that the race to the bottom is less likely if the weak institutionalization we found persists. For platforms, the ability to attract highly educated, productive workers who provide good service and reliability is a great benefit. For this reason, one might expect them to continue hours flexibility. However, there are indications of a push for longer hours on a number of paltforms. On Uber and Lyft, gamification, nudges, and other behavioral strategies attempt to keep drivers behind the wheel longer (Rosenblat and Stark 2016; Scheiber 2017), likely on account of high attrition (Hall and Krueger 2018). Similarly, anecdotal evidence suggests Airbnb is trying to get its hosts to make their properties more available. If platforms become less tolerant of supplemental earners and the proportion of dependent workers grows over time, satisfaction, hourly wages, and autonomy will decline. Conversely, the availability of alternative options in the larger labor market will regulate this pressure. If jobs are plentiful elsewhere, platforms will be forced to improve conditions. The converse is true for slack labor markets. If substantial diversity does persist it is likely there will be more public attention to the fact that platforms are free-riding on conventional employers who offer full-time work and benefits and platforms may be forced to shoulder costs they are now externalizing. In 2018 and 2019 regulatory protections were on the rise (Schor 2020). However, as we write these words in the midst of the COVID_19 pandemic, the prospect of prolonged and severe unemployment has emerged and with it the likelihood that dependency rises as conventional employment opportunities shrink permanently. If so, the dystopian futures predicted by critics may arrive sooner than even they anticipated.

Acknowledgements This research was funded by the MacArthur Foundation under Subaward \#2011-2618. We are grateful to members of the Connected Learning Research Network for intellectual support, Luka Carfagna and Connor Fitzmaurice for valuable input, and Carolyn Ruh and Michelle Kang for research assistance. Stephen Vallas provided especially valuable comments. We also received useful comments from seminar and workshop participants at the Harvard Business School Digital Initiative, Paris-Dauphine University, INAPP (Roma), Boston University, Barnard College, the Pontifical University-Comillas (Madrid), Ross School of Business, Michigan, and Bentley University.

\section{References}

Ajunwa, I., Greene, D. (2019). Platforms at Work: Automated Hiring Platforms and Other New Intermediaries in the Organization of Work. In Work and Labor in the Digital Age. Vol. 33, edited by S. P. Vallas and A. Kovalainen. Binkley, UK: Emerald (MCB UP).

Altonji, J. G., \& Paxson, C. H. (1988). Labor supply preferences, hours constraints, and hours-wage trade-offs. Journal of Labor Economics, 6(2), 254-276.

Aneesh, A. (2009). Global labor: Algocratic modes of organization. Sociological Theory, 27(4), 347-370.

Attwood-Charles, W. (2019a). Culture, collective identity, and gig work. Boston College.

Attwood-Charles, W. (2019b). Dimensions of platform labor control and the experience of gig couriers. Boston College.

Beck, U. (2000). The brave New World of work. Cambridge: Polity Press.

Berg, J., \& Johnston, H. (2019). Too good to be true? A comment on Jonathan Hall and Alan Krueger's 'an analysis of the labor market for Uber's driver-Partners in the United States. ILR Review, 72(1), 39-68.

Berg, J., \& Rani, U. (2018). Digital labour platforms and the future of work: Towards decent work in the online world. Geneva: International Labour Organization.

Bowles, S. (1985). The production process in a competitive economy: Walrasian, neo-Hobbesian, and Marxian models. The American Economic Review, 75(1), 16-36. 
Bowles, S., Gordon, D. M., \& Weisskopf, T. E. (1986). Power and profits: The social structure of accumulation and the profitability of the postwar U.S. economy. Review of Radical Political Economics, 18(1-2), $132-167$.

Boyer, R., \& Saillard, Y. (Eds.). (2002). Regulation theory: The state of the art. London: Routledge.

Burawoy, M. (1979). Manufacturing consent: Changes in the labor process under monopoly capitalism. Chicago: University of Chicago Press.

Calo, R., \& Rosenblat, A. (2017). The taking economy: Uber, information, and power. Columbia Law Review, $117(6), 1623-1690$.

Cameron, L. D. (2018). Making out while driving: control, coordination, and its consequences in algorithmic work. University of Michigan.

Cameron, L. D. (2020). The good bad job: Autonomy and control in the algorithmic workplace. University of Pennsylvania.

Cansoy, M., Schor J. B. (2019). Who gets to share in the 'sharing economy': Understanding the patterns of participation and exchange in Airbnb. Boston College.

Chen, J. Y. (2018). Thrown under the bus and outrunning it! The logic of Didi and taxi drivers' labour and activism in the on-demand economy. New Media \& Society, 20(8), 2691-2711.

Chen, V. T. (2015). Cut loose: Jobless and hopeless in a flawed system. Berkeley: University of California Press.

Cherry, M. A. (2016). Beyond misclassification: The digital transformation of work. Comparative Labor Law \& Policy Journal, 37(3), 577-602.

Collier, R. B., Dubal, V. B., Carter, C. (2017). Labor platforms and gig work: The failure to regulate. IRLE Working Paper 106(17).

Collins, B., Garin, A., Jackson, E., Koustas, D., Payne, M. (2019). Is gig work replacing traditional employment? Evidence from two decades of tax returns.

Cramer, J., \& Krueger, A. B. (2016). Disruptive change in the taxi business: The case of Uber. American Economic Review, 106(5), 177-182.

Davis, G. F. (2016a). The vanishing American corporation: Navigating the hazards of a new economy. San Francisco: Berrett-Kohler.

Davis, G. F. (2016b). What might replace the modern corporation?: Uberization and the web page Enterprise. Seattle University Law Review, 39, 501-515.

van Doorn, N. (2017). Platform labor: On the gendered and Racialized exploitation of low-income service work in the 'on-demand' economy. Information, Communication \& Society, 20(6), 898-914.

Drahokoupil, J., Piasna, A. (2019). Work in the platform economy: Deliveroo riders in Belgium and the SMart arrangement. SSRN Electronic Journal.

Dubal, V. B. (2017a). The drive to Precarity: A political history of work, Regulation \& Labor Advocacy in San Francisco's taxi \& Uber economies. Berkeley Journal of Employment and Labor Law, 38(1), 73-135.

Dubal, V. (2017b). Wage-slave or entrepreneur? Contesting the dualism of legal worker categories. California Law Review, 105, 65-126.

Edelman, B. G., Geradin, D. (2016). Efficiencies and regulatory shortcuts: how should we regulate companies like Airbnb and Uber. Stanford Technology Law Review, 19(2) (Winter 2016), 293-328.

Etsy. (2013). Redefining entrepreneurship: Etsy sellers' economic impact. New York: Etsy.

Evans, D. S., Schmalensee, R. (2013). The antitrust analysis of multi-sided platform businesses. National Bureau of Economic Research.

Farrell, D., Greig, F. (2017). The online platform economy: Has growth peaked? JPMorgan Chase \& Co. Institute.

Forde, C., Stuart, M., Joyce, S. (2017). The Social Protection of Workers in the Platform Economy. PE614.184. Brussels: European Parliament.

Gray, M. L., \& Suri, S. (2019). Ghost work: How to stop Silicon Valley from building a new global underclass. Boston: Houghton Mifflin.

Gray, M. L., Suri, S., Shoaib Ali, S., Kulkarni, D. (2016). The crowd is a collaborative network. Pp 134-47 in CSCW '16 Proceedings of the 19th ACM Conference on Computer-Supported Cooperative Work \& Social Computing. New York, NY.

Griesbach, K., Reich, A., Elliott-Negri, L., \& Milkman, R. (2019). Algorithmic control in platform food delivery work. Socius: Sociological Research for a Dynamic World, 5, 237802311987004.

Hacker, J. S. (2008). The great risk shift: The new economic insecurity and the decline of the American dream (2nd ed.). New Haven: Yale University Press.

Hagiu, A. (2009). Multi-sided platforms: From microfoundations to design and expansion strategies. Harvard Business School Strategy Unit Working Paper (09-115). 
Hall, J. V., \& Krueger, A. B. (2018). An analysis of the labor market for Uber's driver-Partners in the United States. ILR Review, 71(3), 705-732.

Hall, P. A., \& Soskice, D. (Eds.). (2001). Varieties of capitalism: The institutional foundations of comparative advantage. London: Oxford University Press.

Hatton, E. (2011). The temp economy: From Kelly girls to Permatemps in postwar America. Philadelphia: Temple University Press.

Horton, J. J., Zeckhauser, R. J. (2016). Owning, using and renting: Some simple economics of the "sharing economy". NBER Working Paper 22029.

Huws, U., Spencer, N., Srydal, D. S., Holts, K. (2018). Working in the gig economy. Pp. 153-162 in Work in the Digital Age: Challenges of the Fourth Industrial Revolution, edited by M. Neufeind, J. O'Reilly, and F. Ranft. London: Rowman and Littlefield.

Huws, U., Spencer, N. H., Syrdal, D. S., \& Holts, K. (2017). Work in the European gig economy. Brussels: FEPS Foundation for European Progressive Studies.

Irani, L. (2015a). Difference and dependence among digital workers: The case of Amazon mechanical Turk. South Atlantic Quarterly, 114(1), 225-234.

Irani, L. (2015b). The cultural work of microwork. New Media \& Society, 17(5), 720-739.

Ivanova, M., Bronowicka, J., Kocher, E., Degner, A. (2018). The app as a boss? Control and autonomy in application-based management. Arbeit| Grenze| Fluss - Work in Progress Interdisziplinärer Arbeitsforschung.

Kalleberg, A. L. (2013). Good jobs, bad jobs: The rise of polarized and precarious employment Systems in the United States, 1970s to 2000s. New York: Russell Sage Foundation.

Kalleberg, A. L. (2018). Precarious lives: Job insecurity and well-being in rich democracies. Cambridge: Polity Press.

Kennedy, E. J. (2017). Employed by an algorithm: Labor rights in the on-demand economy. Seattle University Law Review, 40(3), 987-1048.

Kenney, M., Zysman, J. (2016). The rise of the platform economy. Issues in Science and Technology, 61-69.

Kenney, M., Zysman, J.. (2019). Work and value creation in the platform economy. Pp. 13-41 in Work and Labor in the Digital Age. Vol. 33, Research in the Sociology of Work, edited by S. P. Vallas and A. Kovalainen. Binkley, UK: Emerald Group publishing limited.

Kuhn, K. M., \& Maleki, A. (2017). Micro-entrepreneurs, dependent contractors, and Instaserfs: Understanding online labor platform workforces. Academy of Management Perspectives, 31(3), 183-200.

Ladegaard, I., Ravenelle, A., Schor, J. B. (2018). Provider vulnerability in the sharing economy. Boston College.

Lane, C. A. (2011). A company of one: Insecurity, Independence, and the New World of white-collar unemployment. Cornell: ILR Press.

Lee, M. K., Kusbit, D., Metsky, E., \& Dabbish, L. (2015). Working with machines: The impact of algorithmic and data-driven management on human workers. Pp. 1603-1612. Seoul: ACM Press.

Lehdonvirta, V. (2018). Flexibility in the gig economy: Managing time on three online piecework platforms. New Technology, Work and Employment, 33(1), 13-29.

Malin, B. J., \& Chandler, C. (2017). Free to work anxiously: Splintering Precarity among drivers for Uber and Lyft: Splintering Precarity among drivers for Uber and Lyft. Communication, Culture \& Critique, 10(2), 382-400.

Manriquez, M. (2019). The Uberization of the labor market: A case study of Monterrey, Mexico. Research in the Sociology of Work 33.

Manyika, J., Lund, S., Bughin, J., Robinson, K., Mischke, J., \& Mahajan, D. (2016). Independent work: Choice, necessity and the gig economy. New York: McKinsey Global Institute.

Marglin, S. A., \& Schor, J. B. (Eds.). (1989). The Golden age of capitalism: Reinterpreting the postwar experience. Oxford: Oxford University Press.

Neff, G. (2012). Venture labor: Work and the burden of risk in innovative industries. Cambridge: MIT Press.

Parrott, J. A., \& Reich, M. (2018). An Earnings Standard for New York City's App-Based Drivers. New York: The new School: Center for New York City Affairs.

Pasquale, F. (2015). The black box society: The secret algorithms that control money and information. Cambridge: Harvard University Press.

Paul, K. (2019). The Uber drivers forced to sleep in parking lots to make a decent living. The Guardian, may 8.

Pesole, A., Brancati, U., Fernandez-Macias, E. (2018). Platform Workers in Europe. EUR 27275 EN. Luxembourg: Publications Office of the European Union. 
Peticca-Harris, A., deGama, N., Ravishankar, M. N. (2018). Postcapitalist Precarious Work and Those in the 'Drivers' Seat: Exploring the Motivations and Lived Experiences of Uber Drivers in Canada. Organization.

PEW Research Center. (2016). Gig Work, Online Selling and Home Sharing.

Popiel, P. (2017). Boundaryless' in the creative economy: Assessing freelancing on Upwork. Critical Studies in Media Communication, 34(3), 220-233.

Rahman, K. S. (2016). The shape of things to come: The on-demand economy and the normative stakes of regulating 21st-century capitalism. European Journal of Risk Regulation, 7(4), 652-663.

Rahman, K. S., Thelen, K. (2018). Broken Contract: The Rise of the Platform Business Model and the Transformation of Twenty-First Century Capitalism.

Ravenelle, A. J. (2016). Hustle: The lived experience of Workers in the Sharing Economy. New York: PhD Dissertation, City University of New York.

Ravenelle, A. J. (2019). Hustle and gig: Struggling and surviving in the sharing economy. Berkeley: University of California Press.

Robinson, H. C. (2017). Making a digital working class: Uber drivers in Boston, 2016-2017. PhD Dissertation. MIT.

Rochet, J.-C., \& Tirole, J. (2003). Platform competition in two-sided markets. Journal of the European Economic Association, 1(4), 990-1029.

Rogers, B. (2015). The social costs of Uber. The University of Chicago Law Review, 8, 85-102.

Rosenblat, A. (2018). Uberland: How algorithms are re-writing the rules of work. Berkeley: University of California Press.

Rosenblat, A., \& Stark, L. (2016). Algorithmic labor and information asymmetries: A case study of Uber's drivers. International Journal of Communication, 10, 3758-3784.

Ross, A. (2004). No-collar: The humane workplace and its hidden costs. Philadelphia: Temple University Press.

Scheiber, N. (2017). How Uber uses psychological tricks to push its drivers' buttons. The New York Times, April 2.

Scholz, T. (2016). Uberworked and underpaid: How workers are disrupting the digital economy. Cambridge: Polity Press.

Schor, J. B. (1992). The overworked American: The unexpected decline of leisure. New York: Basic Books.

Schor, J. B. (2015). Homo Varians: Diverse motives and economic behavior in the sharing economy. Boston College.

Schor, J. B. (2017). Does the sharing economy increase inequality within the eighty percent?: Findings from a qualitative study of platform providers. Cambridge Journal of Regions, Economy and Society, 10(2), 263-279.

Schor, J. B. (2020). After the gig: How the sharing economy got hijacked and how to win it Back. Berkeley: University of California Press.

Schor, J. B., \& Attwood-Charles, W. (2017). The Sharing Economy: Labor, Inequality and Sociability on forProfit Platforms. Sociology Compass, 11(8), 1-16.

Schor, J. B., \& Bowles, S. (1987). Employment rents and incidence of strikes. The Review of Economics and Statistics, 69(4), 584-592.

Shapiro, A. (2018). Between autonomy and control: Strategies of arbitrage in the 'on-demand' economy. New Media \& Society, 20(8), 2954-2971.

Shapiro, C., \& Stiglitz, J. E. (1984). Equilibrium unemployment as a worker discipline device. The American Economic Review, 74(3), 433-444.

Sharone, O. (2013). Flawed system, flawed self: Job searching and unemployment experiences. Chicago: University of Chicago Press.

Shestakofsky, B. (2017). Working algorithms: Software automation and the future of work. Work and Occupations, 44(4), 376-423.

Standing, G. (2011). The Precariat: The new dangerous class. London: Bloomsbury.

Sundararajan, A. (2016). The sharing economy: The end of employment and the rise of crowd-based capitalism. Cambridge: MIT Press.

Telles, R. Jr. (2016). Digital matching firms: A new definition in the "sharing economy" space. ESA issue brief \#01-16. Office of the Chief Economist: US Department of Commerce.

Thelen, K. A. (2014). Varieties of liberalization and the new politics of social solidarity. Cambridge: Cambridge University Press.

Ticona, J., Mateescu, A., Rosenblat, A. (2018). Beyond disruption: How tech shapes labor across domestic work, and ride-hailing. Data \& Society. 
Tomassetti, J. (2016). Does Uber redefine the firm? The postindustrial corporation and advanced information technology. Hofstra Labor \& Employment Law Journal., 34(1), 1-78.

UCLA Institute for Research on Labor and Employment. (2018). More than a gig: A survey of Ridehailing drivers in Los Angeles. Los Angeles: UCLA.

Vallas, S. P. (2019). Platform capitalism: What's at stake for workers? New Labor Forum, 28(1), 48-59.

Vallas, S. P., Kalleberg, A. L. (2018). Introduction. Pp. 1-30 in Probing Precarious Work: Theory, Research, and Politics. Vol. 31, Research in the Sociology of Work, edited by A. L. Kalleberg and S. P. Vallas. Binkley, UK: Emerald Publishing Limited.

Vallas, S. P., Schor, J. B. (2020). What do platforms do?: Understanding the gig economy. Annual Review of Sociology 46.

Weil, D. (2014). The fissured workplace: Why work became so bad for so many and what can be done to improve it. Cambridge: Harvard University Press.

Wells, K., Attoh, K., Cullen, D. (2019). The Uber Workplace in D.C. Washington, DC: Kalmanowitz initiative for labor and the working poor, Georgetown University.

Wood, A. J., Graham, M., Lehdonvirta, V., \& Hjorth, I. (2019). Good gig, bad gig: Autonomy and algorithmic control in the global gig economy. Work, Employment and Society, 33(1), 56-75.

Publisher's note Springer Nature remains neutral with regard to jurisdictional claims in published maps and institutional affiliations.

Juliet B. Schor teaches at Boston College. An economist and sociologist, Schor's research focuses on issues of work, consumption, and climate. Her books include The Overworked American, The Overspent American, True Wealth, and most recently, After the Gig. She is currently part of an NSF-Future of Work project entitled "The Algorithmic Workplace."

Will Attwood-Charles is Assistant Professor of Sociology at Miami University. His research is on postbureaucratic workplaces. He has studied health care institutions, a makerspace, and a delivery platform. His work has appeared in Sociology Compass, Research in the Sociology of Work, the Socio-Economic Review, and Poetics,

Mehmet Cansoy is Assistant Professor of Sociology at Fairfield University. His research is focused on the relationship between technological change and inequality, especially in the sharing economy. This work focuses on racial discrimination, gentrification, and regulation. Cansoy's work with co-authors, Domesticating the Market: Moral Exchange and the Sharing Economy (2018) has appeared in the Socio-Economic Review, and their book After the Gig (2020) has just been published by University of California Press.

Isak Ladegaard is Assistant Professor of Sociology at University of Illinois at Urbana-Champaign. He is interested in economic sociology, technology and social change, and crime and deviance. His work has appeared in Socio-Economic Review, Social Forces, and British Journal of Criminology. Ladegaard is currently in the final months of a four-year research project on digital drug markets, funded by the National Science Foundation.

Robert Wengronowitz teaches Sociology at Scott County Community College. His teaching and research focus on understanding power and inequality and how individuals and groups can work to create a more socially just and ecologically sustainable world. An environmental sociologist by training, Dr. Wengronowitz has expertise in social movements and cultural studies. His multiple ongoing projects examine challenges to inequality-widening business-as-usual, which is ecologically and socially destructive. 


\section{Affiliations}

Juliet B. Schor ${ }^{1}$ - William Attwood-Charles ${ }^{2} \cdot$ Mehmet Cansoy $^{3} \cdot$ Isak Ladegaard $^{4} \cdot$ Robert Wengronowitz ${ }^{5}$

William Attwood-Charles

attwoow@miamioh.edu

Mehmet Cansoy

mehmet.cansoy.bc@gmail.com

Isak Ladegaard

isak.ladegaard@gmail.com

Robert Wengronowitz

bobbywego@gmail.com

1 Department of Sociology, Boston College, Chestnut Hill, MA 02467, USA

2 Department of Sociology and Gerontology, Miami University, Oxford, OH 45056, USA

3 Department of Sociology, Fairfield University, Fairfield, CT 06824, USA

4 Department of Sociology, University of Illinois at Urbana-Champaign, Champaign, IL 61820, USA

5 Department of Sociology and Anthropology, Augustana College, Rock Island, IL 61201, USA 